States with a circular slide rule scored in such terms suggested that neither patients nor doctors are motivated by actuarial concepts.' To many people an annual risk of 3 in 100 does not seem very different from 3 in 10000 . The concepts of being near the front of the queue and of the potential for moving back seem to be far more readily comprehensible and motivational, in my experience and that of many other users in the pilot studies and subsequently. Now that the disk is available this can be more formally tested.

H TUNSTALL-PEDOF

Cardiovascular Epidemiology Unit,

University of Dundee,

Ninewells Hospital and Medical School,

Dundee DD1 9SY

1 MRFIT Research Group. Multiple risk factor intervention trial risk factor changes and mortality results. $\mathcal{F} A M A 1982 ; 248$ $1465-77$.

2 Kornitzer $M$, De Backer $G$, Dramaix $M$, Kittel F, Thilly $C$, Graffar $M$, et al. Belgian heart disease prevention project: incidence and mortality results. Lancet 1983;i: 1066-71.

3 Tunstall-Pedoe $\mathrm{H}$. The Dundee coronary risk-disk for management of change in risk factors. BMf 1991;303:744-7. (28 September.

+ Shaper AG, Pocock SJ, Phillips AN, Walker M. A scoring system to identify men at high risk of a heart attack. Health Trends to identify men

5 Shaper $\mathrm{AG}$, Walker M. Estimating the risk of heart attack. $B M 7$ 1991:303:1333-4. (23 November.

6 Hall GH, Hamilton WT Coronary risk-disk, BM7 1991:303. 1060. (24 October.)

7 Thorsen RD, Jacobs DR, Grimm RH. Preventive cardiology in practice: a device for risk estimation and counselling in coronary disease. Prev Med 1979;8:548-56.

SIR,-K G M M Alberti argues that diabetes meets all the criteria for inclusion as a key area in the Health of the Nation plan. ${ }^{1}$ Though we agree that diabetes is an important and costly disease, both in human and economic terms, we believe that the various clinical interventions need to be critically examined in terms of their effect on morbidity and mortality in the diabetic population. With few notable exceptions, such as insulin treatment in insulin dependent diabetic patients, there is little direct evidence of benefit from intervention in terms of reduced morbidity and mortality.

We agree with Alberti that the evidence that careful blood glucose control prevents specific complications is indirect and that support for the green paper's recommendation to maintain blood glucose within normal levels must await the results of two large randomised controlled trials. But one of these trials has already clearly shown that strict blood glucose control can cause a twofold to sixfold increase in the rate of severe hypoglycaemia. ${ }^{2}$ If "good" glucose control is to be vigorously pursued, acute diabetic complications may not be as easily avoided as Alberti implies, even with optimal patient education.

Turning to tertiary prevention, Alberti comments that "the progress of nephropathy to end stage renal failure can be slowed by meticulous control of blood pressure and a low protein diet.' In fact, the much cited evidence for the efficacy of antihypertensive treatment comes from uncontrolled before and after trials in $\operatorname{six}^{3}$ and $12^{4}$ patients or from observational studies which are hard to interpret. ${ }^{5}$ Unfortunately, this evidence is regarded as conclusive enough to render placebo controlled trials in these high risk patients unethical, particularly since antihypertensive treatment may, in certain situations, adversely affect renal function and clinical outcome.

By contrast, the high efficacy (around $73 \%{ }^{8}$ ) of laser therapy in preventing blindness in patients with sight threatening retinopathy was shown at an early stage in randomised controlled trials." However, the effectiveness of screening to reduce blindness in the diabetic population has not been evaluated. Clearly this needs to be done, as efficacy in randomised controlled trials is not the same as effectiveness in clinical practice. Lack of agreement about how to screen for retinopathy and who should do it ${ }^{11}$ makes it especially important to evaluate the effectiveness of current practice(s).
It is not yet clear from government statistics whether the incidence of blindness from diabetes has fallen since the introduction of laser therapy, ${ }^{12}$ and the task of monitoring rates of blindness in diabetic patients is not as quick and easy as Alberti implies. Neither will it be easy to monitor, on a large scale, the incidence of the other major complications (amputation, strokes, heart attacks) with routine data sources. ${ }^{13}$ Specific information systems for monitoring quality of care and disease outcomes in diabetes will need to be set up along the lines of the St Vincent action programme, and this will take time and money. The key to reaching the proposed targets of reduced morbidity and mortality is not simply "improvement in the organisation of care"; the strategy must include objective measurement of the efficacy and effectiveness of interventions in people with diabetes.

JUDITH STEPHENSON J H FULLER

Department of Epidemiology and Community Health,

University College and Middlesex School of Medicine, London WIP 7PN

Alberti KGMM. Role of diabetes. BMf 1991;303:769-72. (28 September.

2 Diabetes Control and Complications Trial Research Group. Epidemiology of severe hypoglycaemia in the diabetes contro and complications trial. Am $\mathcal{F}$ Med 1991;90:450-9.

3 Mogensen CE. Long-term antihypertensive treatment inhibitin progression of diabetic nephropathy. $B M \mathcal{F} 1982 ; 285: 685-8$.

4 Parving H-H, Andersen AR, Smidt UM, Hommel E, Mathiese ER, Svendsen PA. Effect of antihypertensive treatment o kidney function in diabetic nephropathy. BMF 1987;294: $1443-7$

Stephenson J. Should we be screening for early diabetic renal disease? F Epidemiol Community Health 1991;45:177-9.

6 Parving HH, Hommel E, Smidt UM. Protection of kidney function and decrease in albuminuria by captopril in insulin dependent diabetics with nephropathy. $B M \mathcal{f}$ 1988;297:108691.

Speirs CJ, Dollery CT, Inman WHW, Rawson NSB, Wilton LV. Postmarketing surveillance of enalapril. II. Investigation of the potential role of enalapril in deaths with renal failure. B.MF 1988:297:830-2.

8 Rohan TE, Frost CD, Wald NJ. Prevention of blindness by screening for diabetic retinopathy: a quantitative assessment. BMF 1989;299:1198-201.

9 British Multicentre Study Group. Photocoagulation for proliferative diabetic retinopathy: a randomised controlled clinical trial using the xenon arc. Diabetologia 1984;26 109-15

10 Diabetic Retinopathy Study Group. Photocoagulation treatmen of diabetic retinopathy. Ophthalmology 1981;88:583-600.

Correspondence. Detecting diabetic retinopathy. BMF 1991 302:174-6.

12 Department of Health and Social Security. Causes of blindnes and partial sight among adults in 1976/77 and 1980/81 in England. London: HMSO, 1988.

13 Williams DRR, Fuller JH, Stevens LK. Validity of routinely collected hospital admissions data on diabetes. Diabetic Med 1989;6:320-4.

SIR,-Chris Sinclair and David Pinder draw attention to the use of years of life lost to describe the burden of disease. 'They point out that this measure is very sensitive to the choice of the cut off age above which deaths are ignored. This draws attention to the other fundamental problem with the years of life lost approach - namely, that is is implicitly ageist and hence inequitable.

We suggest a simple method that removes the need to stipulate a cut off age. At any age a person has a finite statistical expectation of further sur vival, however small: estimates of life expectancy for different ages are readily available. For a given population over a given timé details of people dying can be grouped together by, for example,

Estimated outcome in Dumfries and Galloway (population 147000 ) of some health promotion programmes

\begin{tabular}{|c|c|}
\hline Programme & $\begin{array}{c}\text { Person years } \\
\text { of life } \\
\text { lost prevented }\end{array}$ \\
\hline Breast cancer screening & 87 \\
\hline Hypertension screening and treatment & 110 \\
\hline $\begin{array}{l}\text { Enforcement of speed limits and random breat } \\
\text { testing }\end{array}$ & 171 \\
\hline $10 \%$ Reduction in prevalence of smoking & 336 \\
\hline $20 \%$ Reduction in prevalence of smoking & 672 \\
\hline
\end{tabular}

disease or perhaps geographical area. For these deaths the individual expectations of further survival are then summed and the total number of years of life lost derived. Not only can league tables of causes of death be drawn up but, within a given population, estimates can be made of the likely effectiveness of various interventions (table). No attempt has been made in our analyses to apply quality weightings to years of life "saved."

JAMES W T CHALMERS DAVID A BREEN IAN H MACLEAN

Department of Public Health Medicine Dumfries and Galloway Health Board, Dumfries DG1 2SD

1 Sinclair C, Pinder D. Health of the nation. BMF 1991;303:1199. (9 November.)

Evan JG. Aging and rationing. BMf 1991;303:869-70. (12 October.

Smith A. Qualms about QALYs. Lancet 1987;i:1134-6.

4 Quality of life [editorial]. Lancet 1991;338:350-1.

\section{Measurement of central venous pressure}

SIR, - G A Haywood and colleagues report that central venous pressure is affected by posture. This should not surprise doctors because even first aiders are taught to lay down casualties who are shocked in order to increase cardiac filling. The authors also showed something else that is self evident - that if you measure pressure with a fluid filled manometer, moving a ruler up or down nex to the tube does not alter the level of the meniscus. The authors seem to have gone to elaborate means to determine that in their patients the average vertical distance between the sternal angle and mid-axillary line with the patients supine was $12.5 \mathrm{~cm}$ and with them raised at $45^{\circ}$ it was $9.6 \mathrm{~cm}$

It is a sad reflection on medical knowledge that a major medical journal needs to publish a study that only confirms basic physical and physiological principles.

Huddersfield Royal Infirmary,

PETER WILMSHURST

Huddersfield HD3 3EA

1 Haywood GA, Joy MD, Camm AJ. Influence of posture and reference point on central venous pressure measurement. $B M$ 1991;303:626-7. (14 September.)

\section{Strategy for asthma}

SIR,-P G J Burney put the case for including asthma in Britain's health charter. ${ }^{1}$ To describe asthma as a public health problem is to set it in a new light and may lead to the development of public health programmes to reduce mortality and morbidity from asthma. In the absence of primary prevention, strategies should be developed to promote current management. The development of strategies suggests the need to monitor the attainment of specific goals and targets.

Australia and New Zealand have experienced similar increases in mortality, admission to hospital, and morbidity related to asthma to those in the United Kingdom, although starting from a somewhat higher baseline than the United Kingdom or North America. ${ }^{2}$ Specific targets for asthma were identified in the New Zealand health charter, which focused on reducing deaths from asthma, ${ }^{3}$ and asthma was listed as a major problem in the Australian health goals document,${ }^{4}$ though specific goals and targets were not defined.

In Australia public health interventions for asthma have included a mass media campaign to increase awareness about asthma in the general population and among health professionals. The campaign was coordinated by the National Asthma Campaign, which comprises professional medical bodies and six Australian state asthma foundations.

At the local level, equal access to asthma educa- 